\title{
18. ELECTRICAL CONDUCTION IN OCEANIC GABBROS, HOLE 735B, SOUTHWEST INDIAN RIDGE ${ }^{1}$
}

\author{
Philippe A. Pezard, ${ }^{2,3}$ James J. Howard, ${ }^{4}$ and David Goldberg ${ }^{2}$
}

\begin{abstract}
The resistivity, porosity, and cation exchange capacity of 29 gabbroic samples recovered in Hole 735B during Leg 118 of the Ocean Drilling Program (ODP) were measured in the laboratory at room temperature and atmospheric pressure. The samples of lithologic Units IV and VI containing iron and titanium oxides have the highest electrical conductivity and the largest grain density sampled in Hole 735B. The fresh samples are the most resistive of the data set, and the tectonized samples (either due to plastic or brittle deformation) have intermediate values.

Cation exchange capacity and electrical resistivity measurements performed at four different fluid salinities indicate that surface conduction mechanisms can be ignored for in-situ measurements of electrical resistivity at Site 735. The main conduction mechanisms for electrical current consequently are reduced to (1) electrolytic conduction in the pore space and (2) electronic conduction in metallic grains of the matrix in the presence of Fe-Ti oxides. In the last case, matrix conduction might become the dominant conduction mechanism, which explains the low resistivity values recorded in situ with the dual laterolog in lithologic Unit IV and in the lower part of the hole. The conduction equation is then written as follows:
\end{abstract}

$$
C_{o}=\left[\left(C_{w} / \mathrm{FF}\right)+C_{\text {oxides }}\right],
$$

and the low $m$ value obtained when relating porosity to formation factor with

$$
\mathrm{FF}=(8.04) \phi^{-1.08},
$$

which suggests that the conducting pore space of gabbros is similar to that of mid-ocean ridge basalts (MORB), that is, mainly constituted of cracks and microcracks, as elsewhere observed in thin sections.

\section{INTRODUCTION}

The study of the physical structure of oceanic plates has been a subject of widespread interest in geosciences for the past $50 \mathrm{yr}$, particularly since the advent of plate tectonics in the 1960s. Several DSDP/ODP drilling campaigns (Anderson, Honnorez, Becker, et al., 1985; Donnelly, Francheteau, et al., 1979; and many others) succeeded in penetrating the upper oceanic crust, often as deep as a kilometer, both in young crust near mid-ocean ridges (DSDP Holes 395A and 504B) and in abyssal plains (DSDP Holes 417A, 417D, and 418A). In that context, the most remarkable achievement to date remains DSDP/ODP Hole 504B, where a 600 -m-thick dike complex was drilled, thus confirming the similitude between the structure of oceanic plates and that of ophiolites. However, Hole $504 \mathrm{~B}$ is still at least $500 \mathrm{~m}$ short of layer 3, as indicated by a vertical seismic experiment (Becker, Sakai, et al., 1988). Besides short intervals of peridotites recovered from continental margins (Boillot, Winterer, et al., 1987), international efforts to sample continuously the gabbros of layer 3 or oceanic mantle rocks failed until Leg 118. Consequently, Hole 735B provides for the first time a window into the lower oceanic crust and thus the opportunity to study the physical properties of oceanic gabbros. In particular, porosity and permeability data are important to the study of the hydrological budget of the crust.

${ }^{1}$ Von Herzen, R., Robinson, P. T., et al., 1991. Proc. ODP, Sci. Results, 118: College Station, TX U.S.A. (Ocean Drilling Program).

2 Borehole Research Group of the Lamont-Doherty Geological Observatory, Palisades, NY 10964.

3 Department of Geological Sciences of Columbia University, NY.

${ }^{4}$ Schlumberger-Doll Research, Old Quarry Road, Ridgefield, CT 06877.
Unlike bulk density, acoustic velocity, or electrical resistivity, in-situ measurements of porosity of the oceanic basement are not at present directly measurable using geophysical logs. Whereas porosity is estimated routinely from resistivity (Archie, 1942), nuclear (Ellis, 1987), or acoustic (Wyllie and Gregory, 1953) experiments in sedimentary formations, the very different strucure of the pore space of crystalline rocks, or the presence as traces of elements such as gadolinium or boron (with large capture cross sections to neutrons), has prevented to date the development of an accurate method for deriving porosity in basement from in-situ geophysical measurements. The gabbros recovered in Hole 735B provide an even more complex situation with the presence of conductive iron and titanium oxides (Robinson, Von Herzen, et al., 1989). In this case, matrix conduction mechanisms might become as important as electrolytic or cationitic mechanisms (Pezard, in press), or even dominant, as reported by Drury and Hyndman (1979) for dry oceanic basalts, as metallic oxide grains were observed to be the prime electrical conductor.

The extreme sensitivity of electrical properties to a large number of parameters in fact makes electromagnetic methods a complex and powerful technique for studying large- and small-scale structures of rock formations. Although the known electrical properties of rocks and minerals have been observed to vary more than 24 orders of magnitude in the Earth (Olhoeft, 1981), the measurements performed so far in oceanic crust have covered less than six orders of magnitude. In that respect, in-situ measurements of electrical resistivity respond directly to conductivity changes in the rock surrounding the borehole. The presence of conductive metallic grains such as Fe-Ti oxides in the matrix, or vesicular pores, cracks, and microcracks, either fluid-filled or plugged with precipitated conductive minerals (such as smectites) creates a path 
for current flow. The electrical conduction is consequently a combination of electrolytic mechanism for the pore space and the fluid-filled fractures, surface-mediated ion transport mechanism for conductive minerals, and electronic transport for the metallic part of the matrix.

Here, a series of laboratory measurements is reported to evaluate whether the presence of either (1) alteration minerals or (2) Fe-Ti oxides constitutes a significant contribution to current conduction during resistivity logging. This would cause, for example, estimates of porosity using Archie's law to be too high. The results of this experimental analysis are discussed in terms of electrical conduction mechanisms active during in-situ experiments and are used to constrain the structure of the conductive pore space in oceanic gabbros.

\section{OPERATIONS IN HOLE 735B}

During Leg 118, JOIDES Resolution sailed to the Indian Ocean to drill crustal rocks near the Southwest Indian Ridge, in the vicinity of the Atlantis II Fracture Zone. This fracture zone is one of a series of north-south trending transform faults offsetting the slow-spreading Southwest Indian Ridge (Fig. 1). Site 735 is located to the east of the Atlantis II transform, on a narrow platform lying in about $700 \mathrm{~m}$ of water. The position of the platform in the magnetic anomaly pattern on the east transform wall suggests a crustal age of about 12 Ma (Robinson, Von Herzen, et al., 1989). A total of $500.7 \mathrm{~m}$ were drilled; $434.8 \mathrm{~m}$ of olivine gabbro, olivine-bearing gabbro, pyroxene gabbro, Fe-Ti oxide gabbro, troctolite, and microgabbro with rare basalt and trondhjemite were collected in the core. Recovery thus was excellent, with an average of $87 \%$. In addition, an extensive suite of in-situ measurements was conducted over the entire length of this drill hole.

\section{LITHOSTRATIGRAPHIC SEQUENCE}

In all, six major lithologic units were recognized in the penetrated sequence, with rocks having undergone varying degrees of plastic and brittle deformation (Robinson, Von Herzen, et al., 1989). Figure 2 depicts a series of continuous in-situ measurements recorded in Hole $735 \mathrm{~B}$, including resistivity, vertical magnetic field, silica, and photoelectric effect. These measurements illustrate the six different lithology units described in the core. Unit $I$ is a $37.4-\mathrm{m}$-thick sequence of foliated metagabbro with porphyroclastic to mylonitic textures. The igneous textures have been completely destroyed, and a few Fe-Ti oxide-rich layers were observed. Unit II consists of $132.8 \mathrm{~m}$ of olivine and olivine-bearing gabbro. Unit III is a 53.4-m-thick sequence of olivine gabbro with a few intervals of Fe-Ti oxide gabbro. A well-developed igneous lamination dips steeply in the upper part of the unit, but flattens with depth, and mylonitic or foliated zones are common. Unit IV is made up of $50.5 \mathrm{~m}$ of $\mathrm{Fe}$-Ti oxide-rich gabbro. These gabbros have more abundant opaque minerals (10\% or more) and less olivine than those of Unit III. Iron-oxide contents can be as high as $30 \mathrm{wt} \%$, and titanium-oxide contents as high as $9 \mathrm{wt} \%$. A felsic intrusion breccia with trondhjemite veins occurs at two levels within the unit. Unit V consists of $108.3 \mathrm{~m}$ of relatively uniform olivine gabbro characterized by a scarcity of Fe-Ti oxides, and low-calcium pyroxenes similar to those of Unit II. Thin troctolite layers and several plagioclase-rich zones are present. Unit VI is a 118.3-m-thick interval of olivine-rich gabbro with frequent layers of troctolite. These gabbros are similar to those of Unit $\mathrm{V}$, but are enriched in olivine. The troctolite and troctolitegabbros are interlayered with the olivine-gabbros and have been interpreted as small dikes or intrusive layers. These are the most mafic rocks encountered in Hole 735B. A few coarse-grained $\mathrm{Fe}$-Ti oxide-rich gabbros also are present.

\section{CORE MEASUREMENTS}

A total of 29 gabbroic minicores were sampled during Leg 118 to measure porosity, grain density, electrical resistivity at four different saturating-fluid salinities, and cation exchange

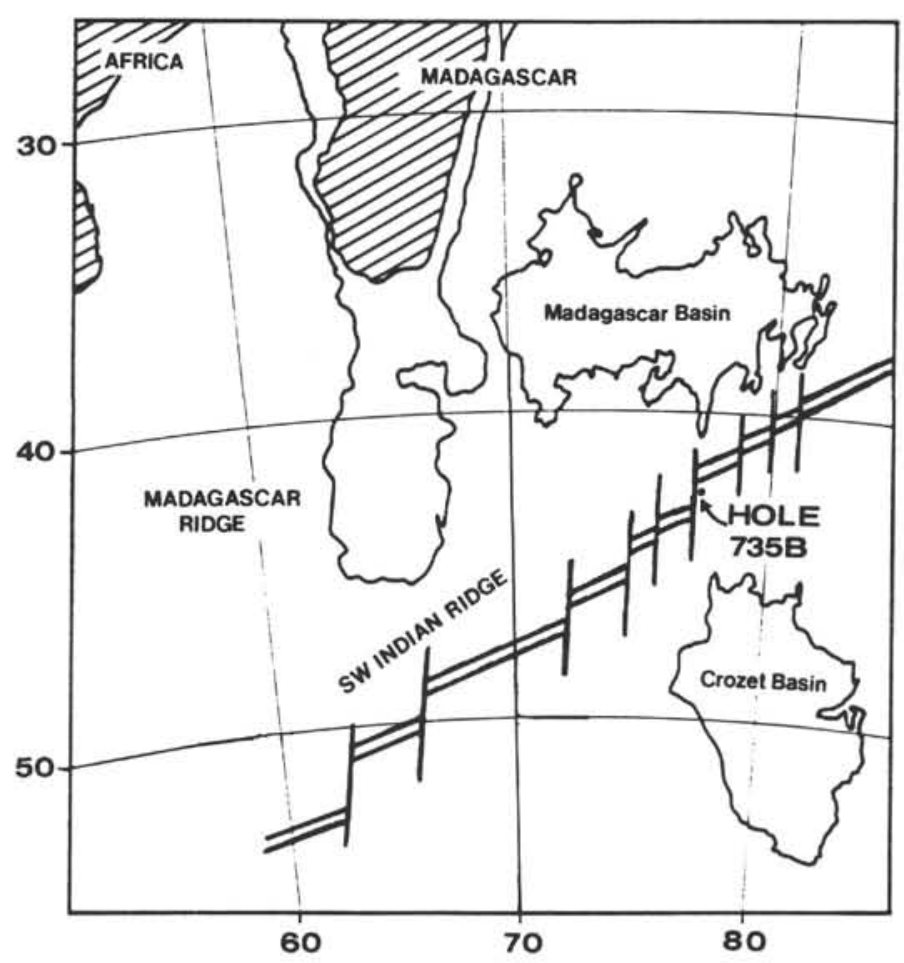

Figure 1. Location map of the drill site on the Southwest Indian Ridge. 


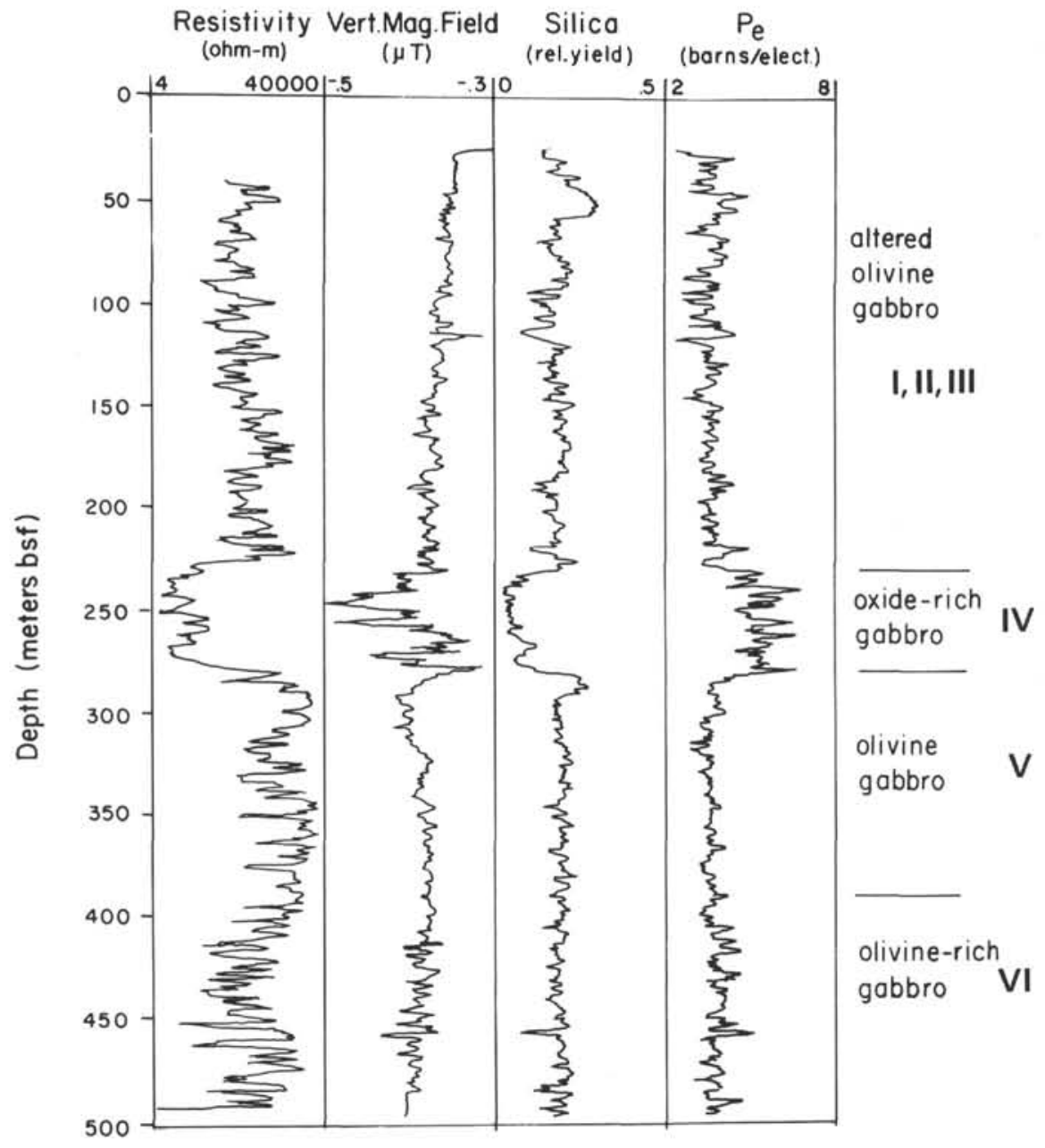

Figure 2. Selected logs in Hole 735B, drilled in layer 3 gabbros. Unit IV, for example, correlates to low electrical resistivity, variable magnetic field, low silica content, and high photoelectric effect $\left(P_{e}\right)$, which indicates a high concentration of conductive $\mathrm{Fe}$-Ti oxides.

capacity (CEC). Minicores were cut from the core on board the ship and immediately stored in seawater to prevent desaturation. Before measuring the resistivity, the samples were saturated with distilled water to eliminate the salts present in the pore spaces. Subsequently, the samples were dried for weight measurements, then saturated under nearvacuum conditions with a 0.195 ohm-m NaCl solution. During the measurements, the samples were kept saturated, and the bath was regularly checked for constant salinity. The 29 samples were selected from each of the six lithologic units (Table 1) and classified for simplicity of reporting into three categories: fresh, tectonized, and Fe-Ti oxide-rich.

\section{Cation Exchange Capacity}

The measurement of CEC is often used in oil and gas exploration to evaluate the shaliness of a sedimentary formation (Waxman and Smits, 1968). The objective of this electrochemical analysis is to count the number of cations that might contribute to the conduction of current during an electromagnetic experiment. As smectites are characterized by large CEC numbers (Serra, 1984; Ellis, 1987), the contribution of saponites (present as alteration phases of MORB in Hole 504B) to in-situ electrical conduction was documented by Pezard (in press) in a study similar to this one. A standard technique for measuring the CEC of rocks called the Kjeldahl method was described by Ridge (1983). A cation not native to the rock is first fixed on the exchangeable clay sites, then the fixed cations are deliberately removed and their quantity measured.

A small amount of material for each of the 29 samples was crushed, and a quantity of 1 to $2 \mathrm{~g}$ was selected after thorough mixing. The samples were made water-wet to disperse the clays, then washed and centrifuged three times with ammonium acetate to locate an ammonium ion at each of the potential exchangeable sites. Once diluted with water and ethyl alcohol, sodium hydroxide was used to replace the ammonium ions. Finally, the ammonium ions were condensed in a reducing environment, collected as ammonia, and titrated in the Kejdahl unit with hydrochloric acid. The results are expressed in milli-equivalents per $100 \mathrm{~g}$ of wet rock (meq/100 $\mathrm{g}$ ), or in milli-equivalents per liter $(\mathrm{meq} / \mathrm{L})$, if converted into a CEC per unit pore volume, $Q_{v}$ (Clavier et al., 1977). Laboratory tests on standards indicate that this technique has a precision of $0.1 \mathrm{meq} / 100 \mathrm{~g}$, and a sensitivity of the order of 0.5 $\mathrm{meq} / 100 \mathrm{~g}$.

\section{Porosity, Grain Density, and Electrical Resistivity}

Porosity and electrical resistivity were measured on the 29 minicores of gabbro, each of which was $25 \mathrm{~mm}$ in diameter and 18 to $23 \mathrm{~mm}$ long. The samples were cut from the 
Table 1. Resistivity (at four different saturating-fluid salinities), porosity, grain density, and CEC of 29 samples.

\begin{tabular}{|c|c|c|c|c|c|c|c|c|c|c|c|c|c|}
\hline Sample & $\begin{array}{l}\text { Depth } \\
\text { (mbsf) }\end{array}$ & $\begin{array}{c}\text { Lithologic } \\
\text { unit }\end{array}$ & $\begin{array}{l}\text { Core, section } \\
\text { (118-735B-) }\end{array}$ & Sample & $\begin{array}{l}\text { Porosity } \\
(\phi)\end{array}$ & $\begin{array}{c}\text { Grain } \\
\text { density }\end{array}$ & CEC & $\begin{array}{c}\text { Res } \\
(0.052)\end{array}$ & $\begin{array}{c}\text { Res } \\
(0.195)\end{array}$ & $\begin{array}{c}\text { Res } \\
(0.502)\end{array}$ & $\begin{array}{c}\text { Res } \\
(1.020)\end{array}$ & FF & $\begin{array}{c}B \cdot Q_{v} \\
(\mu=10.0)\end{array}$ \\
\hline 1 & 20.00 & I & $06-1$ & Fresh & 0.011 & 2.91 & 4.8 & 52.9 & 238.1 & 322.6 & 344.8 & 1017.5 & 0.452 \\
\hline 2 & 40.00 & I & $12-1$ & Tectonized & 0.029 & 2.83 & 1.2 & 20.5 & 67.6 & 109.9 & 119.8 & 394.4 & 0.040 \\
\hline 3 & 52.45 & II & $14-2$ & Tectonized & 0.017 & 3.00 & 1.2 & 44.5 & 163.9 & 222.2 & 238.3 & 855.6 & 0.072 \\
\hline 4 & 98.87 & II & $22-4$ & Tectonized & 0.028 & 2.95 & 1.1 & 23.1 & 61.2 & 102.6 & 113.8 & 444.7 & 0.040 \\
\hline 5 & 142.98 & II & $30-5$ & Fresh & 0.007 & 2.99 & 5.8 & 89.0 & 370.4 & 607.2 & 714.3 & 1710.8 & 0.548 \\
\hline 6 & 146.43 & II & $31-3$ & Fresh & 0.010 & 3.00 & 4.0 & 60.5 & 322.6 & 581.7 & 666.7 & 1164.0 & 0.400 \\
\hline 7 & 152.31 & II & $32-4$ & Tectonized & 0.014 & 2.79 & 4.2 & 42.1 & 147.1 & 204.1 & 219.4 & 809.6 & 0.286 \\
\hline 8 & 191.45 & III & $40-1$ & Fresh & 0.011 & 2.93 & 2.6 & 52.0 & 158.7 & 294.1 & 319.5 & 999.7 & 0.229 \\
\hline 9 & 201.36 & III & $41-4$ & Fresh & 0.007 & 2.99 & 1.2 & 76.3 & 303.0 & 492.6 & 545.8 & 1467.1 & 0.185 \\
\hline 10 & 225.00 & IV & $47-3$ & Fresh & 0.008 & 3.01 & 2.8 & 62.2 & 322.6 & 485.4 & 534.2 & 1195.8 & 0.348 \\
\hline 11 & 231.93 & IV & $48-1$ & Fe-Ti oxides & 0.011 & 3.24 & 2.3 & 8.8 & 12.6 & 14.0 & 14.5 & 168.4 & 0.245 \\
\hline 12 & 242.81 & IV & $50-4$ & Fe-Ti oxides & 0.005 & 3.17 & 1.9 & 15.1 & 23.3 & 26.2 & 28.0 & 290.8 & 0.412 \\
\hline 13 & 254.86 & IV & $53-2$ & Fe-Ti oxides & 0.008 & 3.20 & 2.6 & 22.8 & 38.0 & 49.8 & 52.2 & 438.1 & 0.375 \\
\hline 14 & 257.83 & IV & $53-4$ & Tectonized & 0.018 & 2.95 & 3.7 & 30.2 & 101.6 & 140.8 & 153.3 & 581.2 & 0.205 \\
\hline 15 & 272.37 & IV & $56-2$ & Fe-Ti oxides & 0.009 & 3.26 & 2.2 & 10.6 & 17.5 & 22.9 & 24.5 & 203.8 & 0.289 \\
\hline 16 & 279.59 & V & $57-4$ & Tectonized & 0.045 & 2.87 & 5.4 & 12.5 & 45.2 & 68.0 & 75.9 & 240.3 & 0.114 \\
\hline 17 & 281.96 & V & $58-2$ & Fresh & 0.009 & 3.00 & 2.3 & 59.1 & 309.2 & 555.6 & 645.2 & 1136.5 & 0.259 \\
\hline 18 & 300.77 & V & $61-4$ & Fresh & 0.014 & 2.90 & 2.5 & 36.8 & 157.5 & 322.6 & 424.4 & 707.7 & 0.181 \\
\hline 19 & 306.43 & V & $63-1$ & Tectonized & 0.029 & 2.89 & 2.8 & 23.1 & 75.8 & 119.0 & 141.6 & 443.8 & 0.096 \\
\hline 20 & 363.86 & V & $72-5$ & Fresh & 0.007 & 3.00 & 1.4 & 78.7 & 378.0 & 571.4 & 646.6 & 1513.6 & 0.221 \\
\hline 21 & 371.41 & V & $73-5$ & Fresh & 0.009 & 2.99 & 1.5 & 61.7 & 322.6 & 540.5 & 611.3 & 1187.2 & 0.165 \\
\hline 22 & 407.83 & VI & $77-3$ & Fresh & 0.008 & 2.95 & 2.2 & 81.5 & 435.1 & 628.9 & 714.3 & 1567.7 & 0.285 \\
\hline 23 & 411.68 & VI & $78-2$ & Tectonized & 0.031 & 2.91 & 2.6 & 17.9 & 72.5 & 91.7 & 101.8 & 344.7 & 0.084 \\
\hline 24 & 420.48 & VI & $79-5$ & Fe-Ti oxides & 0.008 & 3.18 & 3.0 & 6.1 & 10.9 & 12.6 & 13.8 & 118.0 & 0.430 \\
\hline 25 & 432.85 & VI & $80-7$ & Fe-Ti oxides & 0.007 & 3.26 & 2.6 & 7.4 & 9.8 & 10.2 & 10.5 & 141.9 & 0.430 \\
\hline 26 & 477.76 & VI & $85-5$ & Tectonized & 0.033 & 2.94 & 3.0 & 18.7 & 64.4 & 98.3 & 104.2 & 360.6 & 0.090 \\
\hline 27 & 488.25 & VI & $86-5$ & Fresh & 0.009 & 2.88 & 1.4 & 56.3 & 243.3 & 429.5 & 505.0 & 1083.3 & 0.156 \\
\hline 28 & 488.43 & VI & $86-6$ & Fresh & 0.011 & 2.81 & 3.7 & 47.3 & 224.9 & 390.3 & 483.5 & 909.8 & 0.326 \\
\hline 29 & 491.38 & VI & $87-1$ & Fe-Ti oxides & 0.012 & 3.28 & 2.8 & 11.9 & 21.8 & 22.6 & 23.3 & 228.6 & 0.274 \\
\hline
\end{tabular}

$\mathrm{CEC}=$ cation exchange capacity; $\mathrm{FF}=$ formation factor; $\mathrm{Res}=$ resistivity.

working-half of the cores recovered from Hole 735B, perpendicular to the axis of the original core. Electrical resistivities were measured along the axis of the minicores, and thus are representative of the "horizontal" resistivity of the bulk rock.

Porosity was determined by standard immersion methods. The core plugs were saturated with distilled water in an evacuation cell for $48 \mathrm{hr}$. For dry weights, the plugs were dried at $65^{\circ} \mathrm{C}$ for $12 \mathrm{hr}$, then placed at near-vacuum conditions. Because the instrument resolution is $\pm 0.0001 \mathrm{~g}$ and the reproducibility is $\pm 0.0005 \mathrm{~g}$, an experimental error for porosity of $\pm 0.10 \%$ ( $20 \%$ of the absolute value for the less porous samples) is inherent to this technique. The electrical resistivity of the samples was measured at $24.5^{\circ} \mathrm{C}$ and atmospheric pressure, after being saturated again with a $0.195 \mathrm{ohm}-\mathrm{m} \mathrm{NaCl}$ solution. A $10-\mathrm{mV}, 50-\mathrm{Hz}$ signal was applied to the samples with a Wayne-Kerr bridge for measuring at a frequency similar to those used in-situ by the dual laterolog. Resistivity was measured with a two-electrode device (Brace et al., 1965; Rai and Manghnani, 1981; Pezard, in press) by attaching stainless-steel electrodes to both ends of each core plug. A teflon wrapping was applied to the cylinder surfaces to prevent desaturation while measuring. Although the instrumental error for resistivity measurements is about $1 \%$, the overall error was as high as $5 \%$ because of the difficulty in achieving a reproducible contact between the samples and the steel electrodes.

\section{RESULTS AND DISCUSSION}

The results of the physical and chemical properties measured in samples from Hole 735B are summarized in Table 1 and in Figure 3. A crossplot of grain density vs. electrical resistivity provides a definition of the three categories previously chosen to distinguish alteration (Fig. 3). The Fe-Ti oxide-rich samples are the most conductive and have the largest grain densities. As expected, the fresh samples are the most resistive, and tectonized samples have intermediate
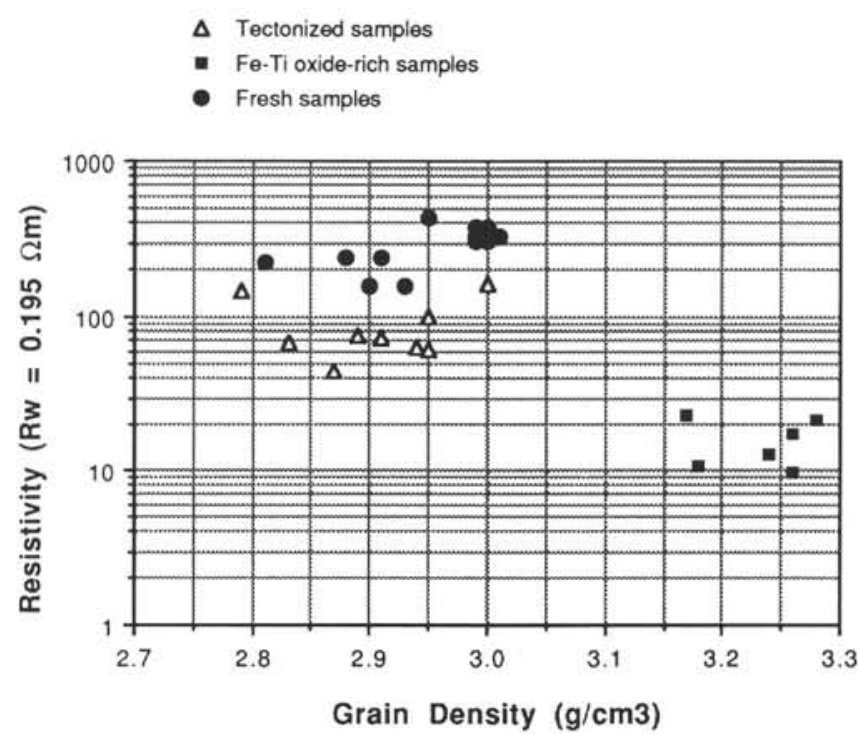

Figure 3. Grain density vs. resistivity (measured with seawater as saturating fluid).

resistivity values (Fig. 3). A plot of grain density, porosity, resistivity, and CEC as a function of depth is presented in Figure 4 . Porosity values are on the order of $1.0 \%$ for fresh and oxide-rich samples and $3.0 \%$ for tectonized samples. The oxide-rich samples from Units IV and VI cannot be distinguished on the basis of these measured properties.

CEC measurements do not follow the same classificationscheme defined by the electrical-resistivity or grain-density crossplot (Fig. 3). Although the CEC does not show any correlation with resistivity (Fig. 5), the contribution of surface 

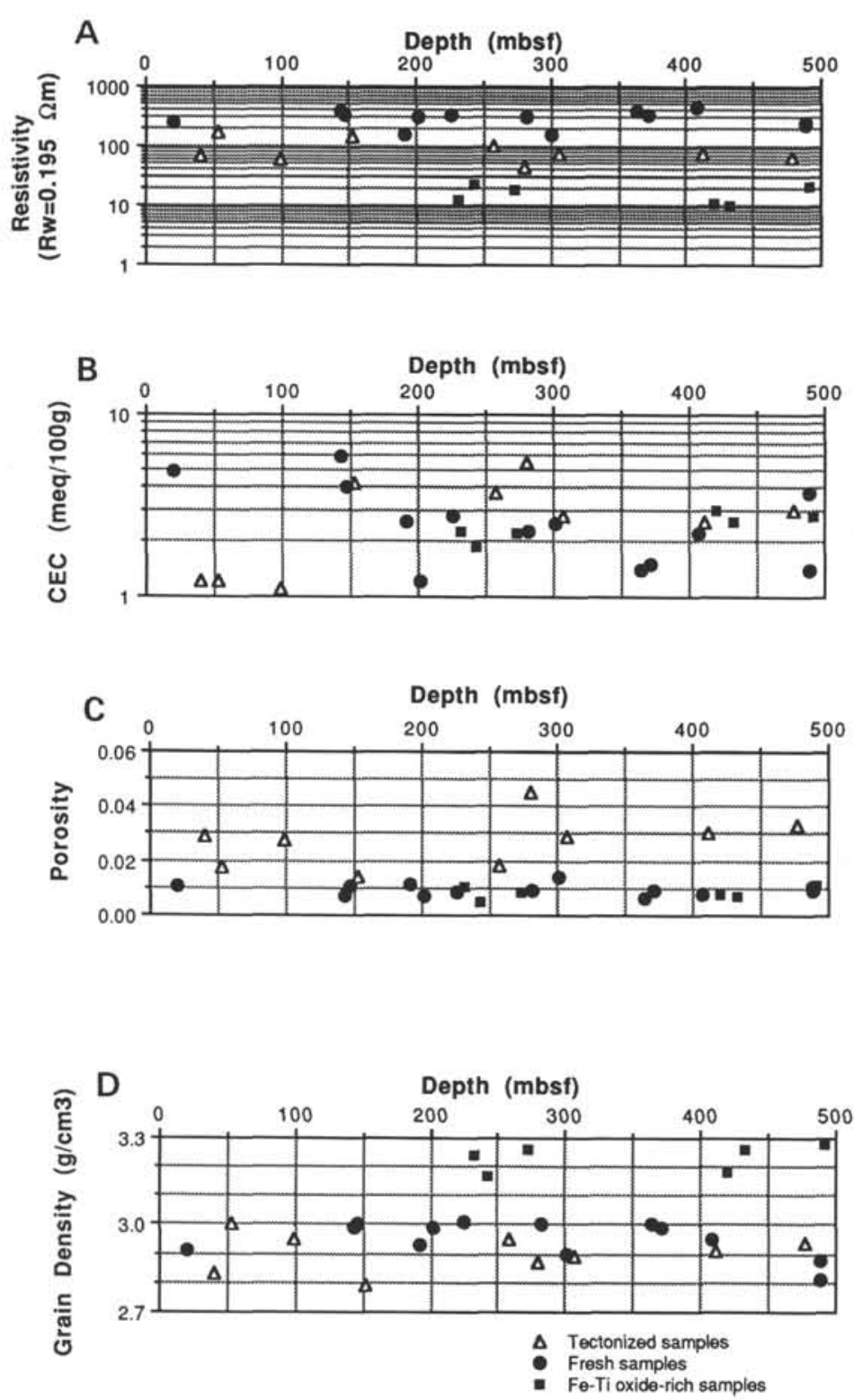

Figure 4. A. Resistivity (at seawater salinity); B. CEC; C. Porosity; D. Grain density; vs. depth.

conduction $\left(B \cdot Q_{V} / \mu^{2}\right)$ appears to be nearly constant, regardless of sample resistivity (Fig. 6). An exception to this is constituted by a few tectonized samples having low CEC values in the upper part of Hole 735B (Units I and II; Fig. 4A). The surface conduction contribution was computed according to the model of parallel conduction between pore volumes and pore surfaces (Pezard, in press). This is described by

$$
\mathrm{FF}=\left[C_{w}+\left(B \cdot Q_{v} / \mu^{2}\right)\right] / C_{o},
$$

where $\mathrm{FF}=$ the formation factor of the rock corrected for clay conductivity, $C_{w}=$ the conductivity of the pore fluid, $B=$ the equivalent conductance of the sodium ions absorbed onto the pore surfaces, $Q_{v}=$ the CEC of the rock per unit pore volume, $\mu^{2}=$ a dimensionless number meant to compensate for the tortuosity of the pore surfaces with respect to that of the pore space, and $C_{o}=$ the conductivity of the fluid-bearing rock.
- Fresh samples

$\Delta$ Tectonized samples

- Fe-Ti oxide-rich samples

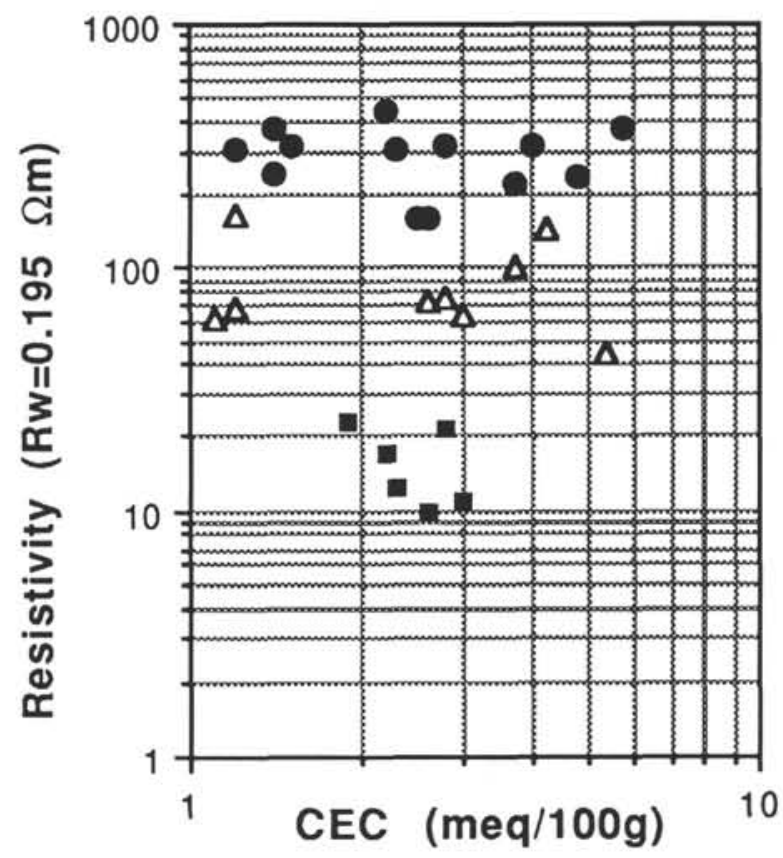

Figure 5. CEC vs. resistivity (at seawater salinity).

As boundary conditions for this model, values of $\mu$ equal to 1.0 or 100.0 , respectively, would provide values of $\left(B \cdot Q_{\downarrow} / \mu^{2}\right)$ either too large or too small to be significant. A value of $\mu=$ 10.0 thus was chosen to model the surface conduction. Figure 6 shows that surface conduction contributes little, if at all, to the overall electrical conduction during in-situ measurements, as $C_{w}$ equals about $5000.0 \mathrm{~m} \Omega^{-1} \mathrm{~m}^{-1}$, compared to $\left(B \cdot Q_{v} / \mu^{2}\right)$, which is of the order of $25.0 \mathrm{~m} \Omega^{-1} \mathrm{~m}^{-1}$ for $\mu=10.0$. For the few anomalous samples from the upper part of Hole $735 \mathrm{~B}$ with low CEC values (Units I and II), the contribution of surface conduction is even smaller.

\section{Electrical Conduction in Gabbros}

The two resistivity-porosity crossplots in Figure 7 show that fresh and tectonized samples can be related by a regression similar to that of Winsauer and McCardell (1953). However, the oxide-rich samples do not follow the same line. This suggests the existence of at least two dominant mechanisms for electrical conduction in the rocks recovered from Hole $735 \mathrm{~B}$. Figures 8 and 9 summarize the conductivities measured at four different saturating-fluid salinities. Whereas no consistent rule results from the grouping of samples based on the lithostratigraphic zonation (Fig. 8), similar relationships do appear when grouping is based on fresh, altered, and oxiderich samples (Fig. 9).

As expected, fresh samples are the most resistive and oxide-rich samples the most conductive. However, it appears that (1) surface conduction contributes little to the conductivity of the samples at seawater salinity in the case of fresh or tectonized samples and (2) both surface and electrolytic conductions can be ignored at seawater salinity $\left(C_{w}=5.0 \Omega^{-1}\right.$ $\mathrm{m}^{-1}$ ) for Fe-Ti oxide-rich samples. These two points might be illustrated as follows. At seawater salinity $\left(C_{w}=5.0 \Omega^{-1} \mathrm{~m}^{-1}\right)$, the sample conductivity increases with fluid salinity (or con- 


\section{- Fe-Ti oxide-rich samples \\ $\Delta$ Tectonized samples \\ - Fresh samples}

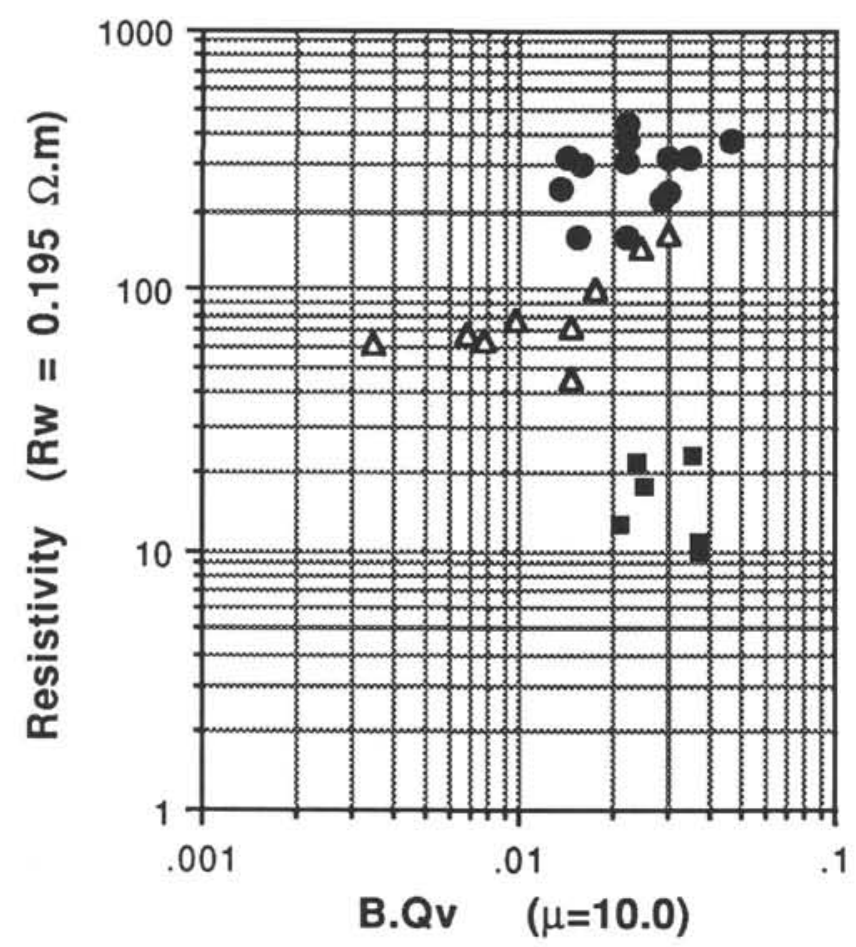

Figure 6. Surface conductivity vs. resistivity (at seawater salinity). ductivity) for fresh and tectonized samples, thereby proving that the main conduction mechanism in this salinity domain is electrolytic (Pezard, in press). For Fe-Ti oxide-rich samples, the rock conductivity is near-constant at seawater conductivity $\left(C_{w}=5.0 \Omega^{-1} \mathrm{~m}^{-1}\right)$, and the main conduction mechanism then is attributed to the high concentration of metallic oxides in the matrix. As a consequence, the conduction of electrical current for the gabbros recovered in Hole $735 \mathrm{~B}$ can be described by a model of electrical conduction in parallel:

$$
C_{o}=\left(C_{w} / \mathrm{FF}\right)+C_{\text {oxides }},
$$

where $C_{\text {oxides }}$ is the conduction component from the presence of metallic oxides in the matrix. Each of the 29 samples will be analyzed in the future for oxide content to study the potential relationship of $C_{\text {oxides }}$ to oxide concentration.

\section{Porosity and Formation Factor}

The study is now restricted to nonoxide-bearing samples, where one can assume that $C_{\text {oxides }}$ is negligible. The relationship observed in Figure 7 (at $R_{w}=1.02 \mathrm{ohm}-\mathrm{m}$ ) is valid for each saturating-fluid salinity (Fig. 10), both for fresh (Fig. 11) and tectonized samples (Fig. 12). In both cases, the best fit is obtained with the most saline saturating-fluids. An average of the results obtained for the two most saline fluids (including seawater for $R_{w}=0.195 \mathrm{ohm}-\mathrm{m}$ ) has been computed, and the following regression provides a means of estimating porosity from resistivity:

$$
\mathrm{FF}=C_{w} / C_{o}=(8.04) \times \phi^{-1.08} .
$$

This result is similar to that derived for MORB from DSDP Hole 418A (Broglia and Moos, 1988) and Hole 504B (Pezard, in press), subaerial basalts from Iceland (Flovenz et al., 1985), or even granites (Pape et al., 1985). The low $m$ value (near 1.0) implies that the structure of the pore space of gabbros from Hole $735 \mathrm{~B}$ is constituted of large aspect-ratio cracks and microcracks pervasively interconnected at the microscopic scale (e.g., Keller and Frischknecht, 1966; Shankland, 1975; Schwartz and Kimminau, 1988).
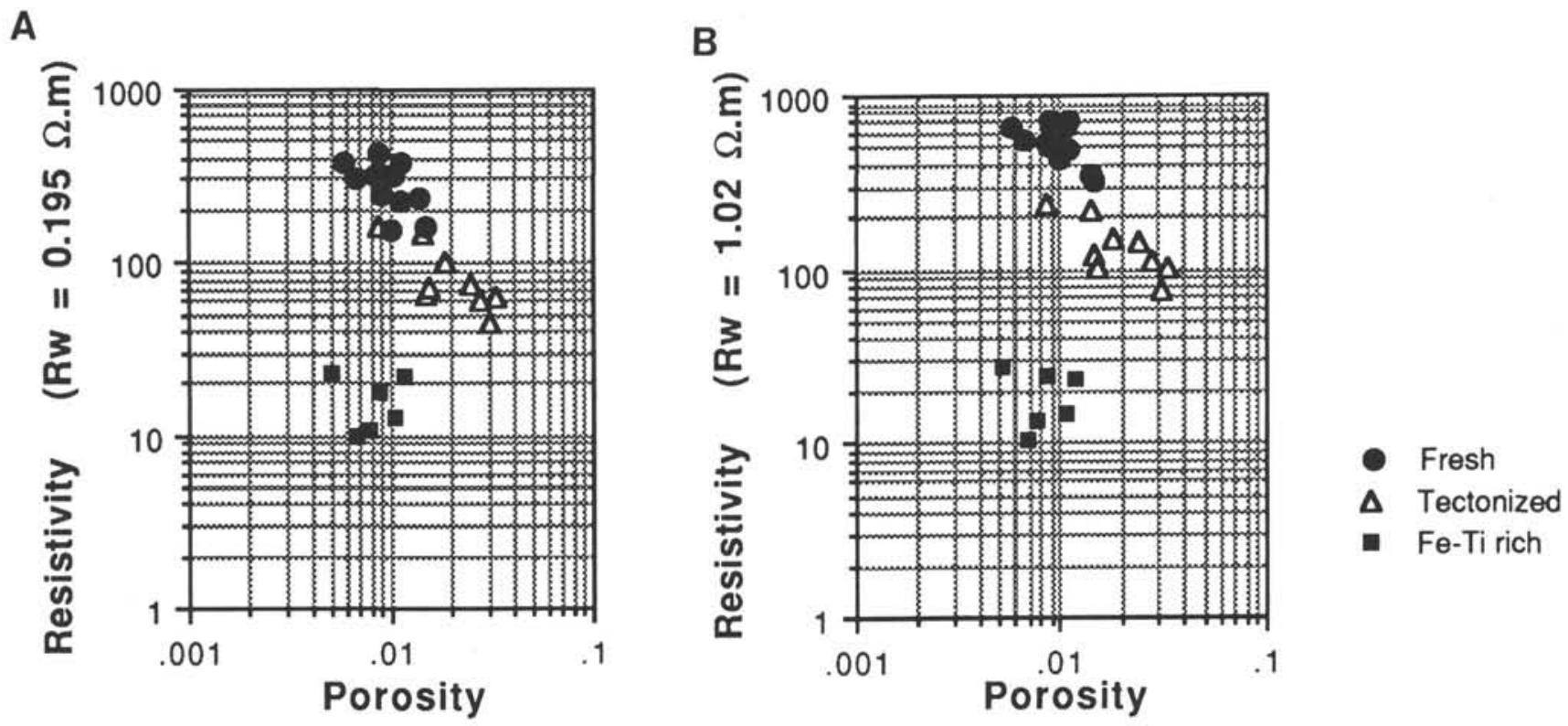

Figure 7. Porosity vs. resistivity at two saturating-fluid salinities: (A) seawater $\left(R_{w}=0.195\right.$ ohm-m) and $(\mathrm{B}) R_{w}=1.02$ ohm-m. 


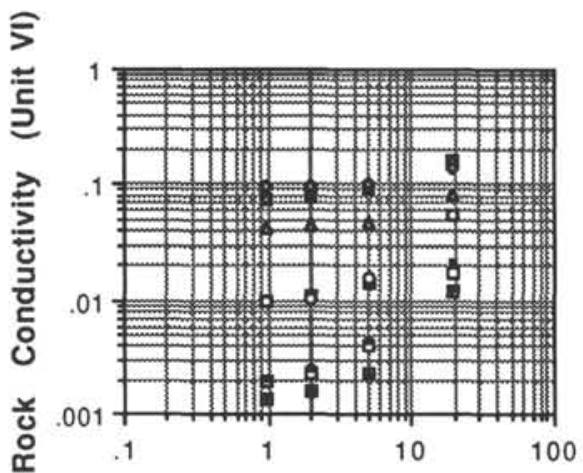

Fluid Conductivity
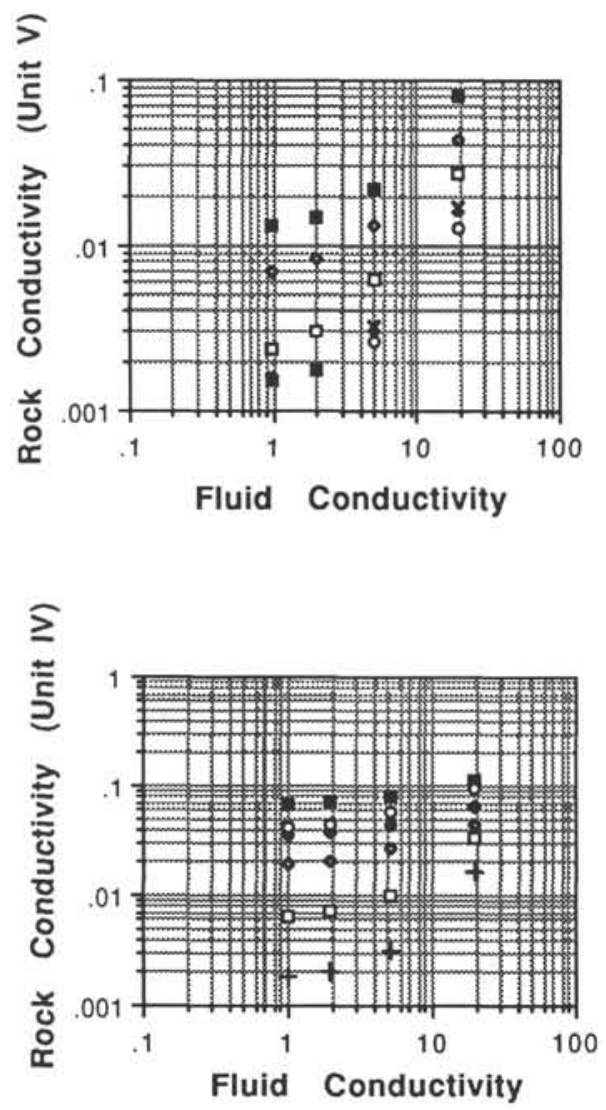
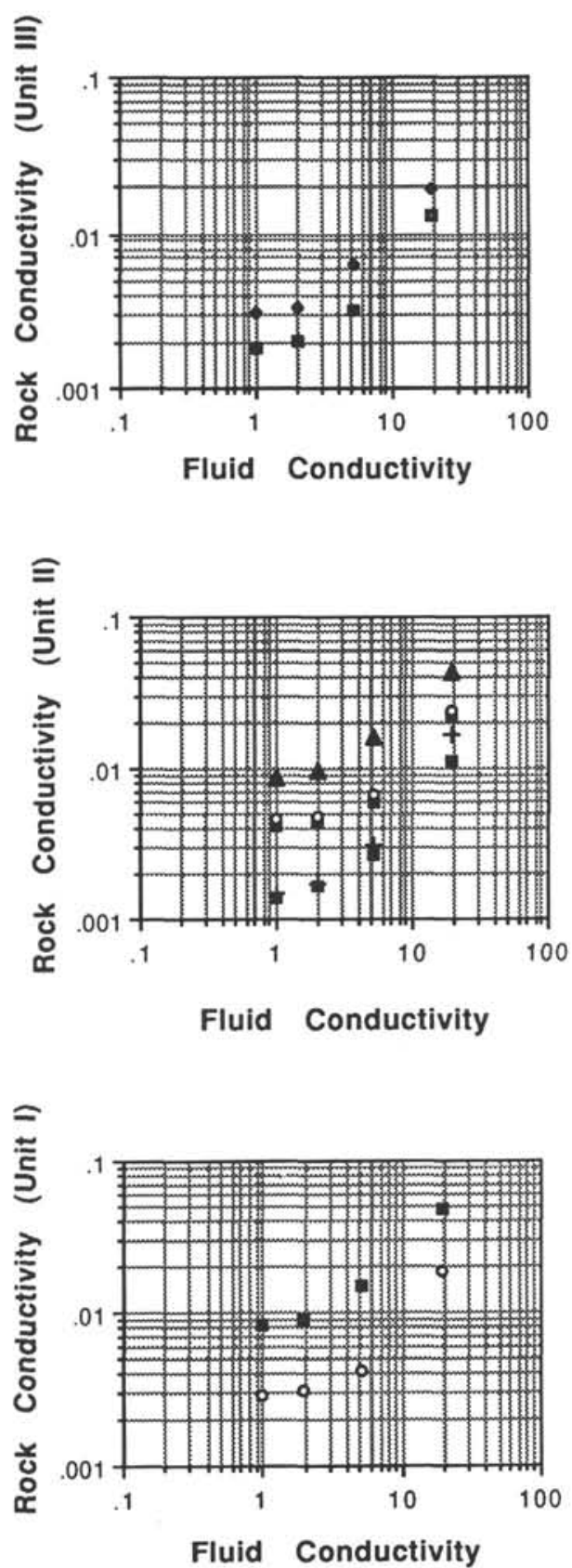

Figure 8. Electrical conductivity at four saturating-fluid salinities classified per lithologic units.

\section{CONCLUSIONS}

Surface conduction mechanisms can be ignored when analyzing downhole measurements of electrical resistivity recorded in gabbros at Site 735. The main conduction mechanisms for electrical current consequently are reduced to (1) electrolytic conduction in the pore space and (2) electronic conduction in metallic grains of the matrix because of the presence of $\mathrm{Fe}-\mathrm{Ti}$ oxides. When a high oxide concentration is present, matrix conduction becomes the dominant conduction mechanism. This explains the low resistivity values recorded in situ with the dual laterolog in lithologic Unit IV and the lower part of the hole. The low $m$ value obtained when relating porosity to formation factor suggests that the conducting pore space of gabbros is similar to that of MORB, that is, mainly composed of cracks and microcracks, as observed elsewhere in thin sections.

\section{ACKNOWLEDGMENTS}

We thank the co-chiefs, Paul Robinson and Richard Von Herzen, for allowing us to sample the rocks recovered during Leg 118; Janice Gittings for her assistance at various stages of this study; Michael Lovell, Mathilde Cannat, and Henriette Lapierre for helping to shape a better manuscript through informal discussions; and Morton Ridge and Larry McGowan of Schlumberger-Doll Research for providing their help with laboratory measurements. This study was supported by the NSF through a JOI/USSAC grant administered by the Texas A\&M Research Foundation. 


\section{REFERENCES}

Anderson, R. N., Honnorez, J., Becker, K., et al., 1985. Init. Repts. $D S D P, 83$ : Washington (U.S. Govt. Printing Office).

Archie, G. E., 1942. The electrical resistivity $\log$ as an aid in determining some reservoir characteristics. J. Pet. Technol., 5:18.

Becker, K., Sakai, H., et al., 1988. Site 504. Proc. ODP, Init. Repts., 111: College Station, TX (Ocean Drilling Program).

A

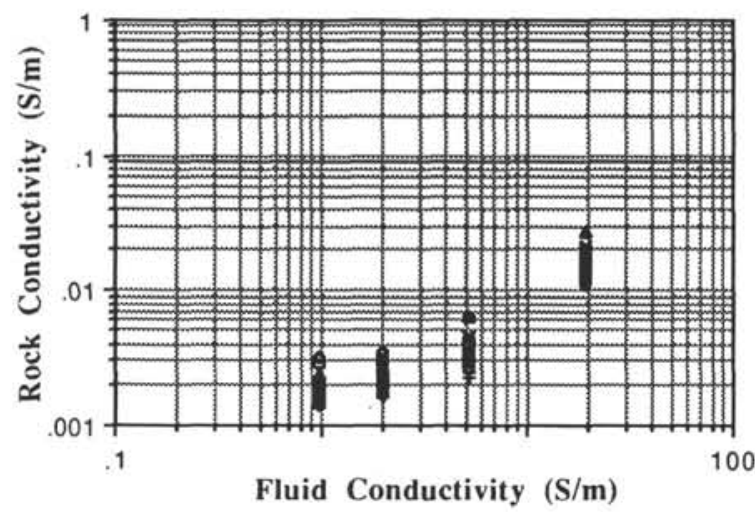

B

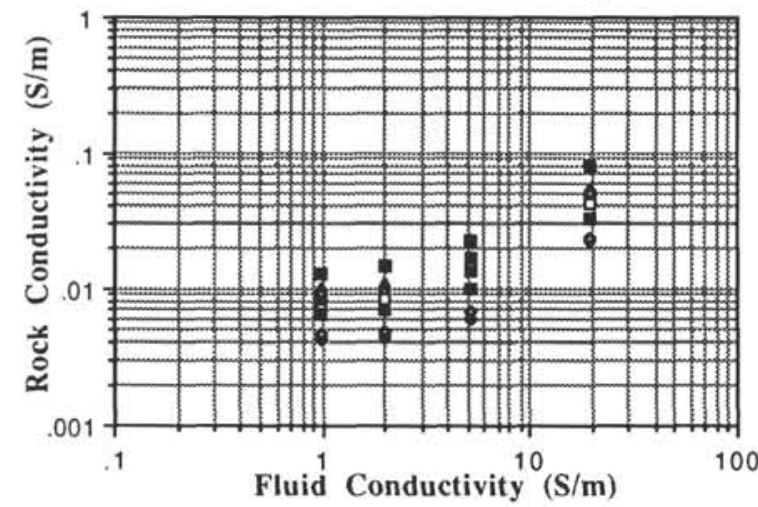

C
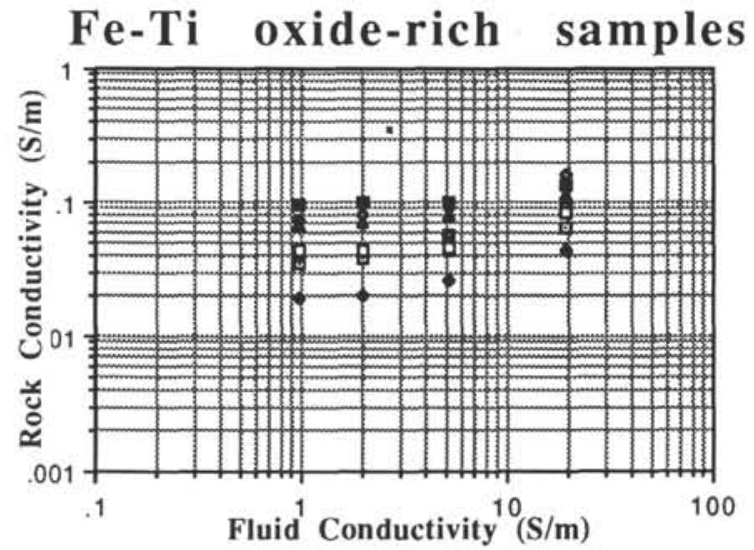

Figure 9. Electrical conductivity at four different saturating-fluid salinities of samples classified in three arbitrary categories: (A) fresh, (B) tectonized, and (C) Fe-Ti oxide-rich samples.
Boillot, G., Winterer, E. L., et al., 1987. Site 637. Proc. ODP, Init. Repts., 103: College Station, TX (Ocean Drilling Program),

Brace, W. F., Orange, A. S., and Madden, T. R., 1965. The effect of pressure on the electrical resistivity of water-saturated crystalline rocks. J. Geophys. Res., 70:5669-5678.

Broglia, C., and Moos, D., 1988. In situ structure and properties of $110 \mathrm{Ma}$ crust from geophysical logs in DSDP Hole 418A. In Salisbury, M. H., Scott, J., et al., Proc. ODP, Sci. Results, 102: College Station, TX (Ocean Drilling Program), 29-47.

Clavier, C., Coates, G., and Dumanoir, J., 1977. The theoretical and experimental bases for the dual-water model for the interpretation of shaly sands. Pap. 6859 presented at the Soc. Pet. Engrs. 52nd Annu. Tech. Conf. (Denver).

Donnelly, T., Francheteau, J., et al., 1979. Inits. Repts. DSDP, 51, 52, 53: Washington (U.S. Govt. Printing Office).

Drury, M. J., and Hyndman, R. D., 1979. The electrical resistivity of oceanic basalts, J. Geophys. Res., 84:4537-4546.

Ellis, D. V., 1987. Well Logging for Earth Scientists: New York (Elsevier).

Flovenz, O. G., Georgsson, L. S., and Arnasson, K., 1985. Resistivity structure of the upper crust in Iceland. J. Geophys. Res., 90:10136-10150.

Keller, G. V., and Frischknecht, F. C., 1966. Electrical Methods in Geophysical Prospecting: Oxford (Pergamon Press).

Olhoeft, G. R., 1981. Electrical properties of rocks. In Touloukian, Y. S., Judd, W. R., and Roy, R. F. (Eds.), Physical Properties of Rocks and Minerals: New York (McGraw-Hill), 257-330.

Pape, H., Riepe, L., and Schopper, J. R., 1985. Petrophysical detection of microfissures in granites. SPWLA 26th Annu. Logging Symp. (Dallas), Pap. P.

Pezard, P. A., in press. Electrical properties of MORB and implications for the structure of the upper oceanic crust at Site 504.J. Geophys. Res.

Rai, C. S., and Manghnani, M. H., 1981. The effect of saturant salinity and pressure on the electrical resistivity of Hawaiian basalts. Geophys. J. Roy. Astron. Soc., 65:395-405.

Ridge, M. J., 1983. A combustion method for measuring the cation exchange capacity of clay minerals. Log Analyst, 3:6-11.

Robinson, P. T., Von Herzen, R. P., et al., 1989. Site 735. Proc. ODP, Init. Repts., 118: College Station, TX (Ocean Drilling Program).

Schwartz, L. M., and Kimminau, S., 1987. Analysis of electrical conduction in the grain consolidation model. Geophysics, 52:1402-1411.

Serra, O., 1984. Fundamentals of Well-Log Interpretation: Amsterdam (Elsevier).

Shankland, T. J., 1975. Electrical conduction in rocks and minerals: parameters for interpretation. Phys. Earth Planet. Int., 10:209219.

Waxman, M. H., and Smits, L.J.M., 1968. Electrical conductivities in oil-bearing shaly sands. Pet. Trans. AIME, 243:240-248.

Winsauer, W. O., and McCardell, W. M., 1953. Ionic double-layer conductivity in reservoir rocks. Pet. Trans. AIME, 198:129-134.

Wyllie, R. J., and Gregory, A. R., 1953. Formation factors of unconsolidated porous media: influence of particle shape and effects of cementation. Pet. Trans. AIME, 198:103-110.

Date of initial receipt: 12 July 1989

Date of acceptance: 4 June 1990

Ms 118B-161 


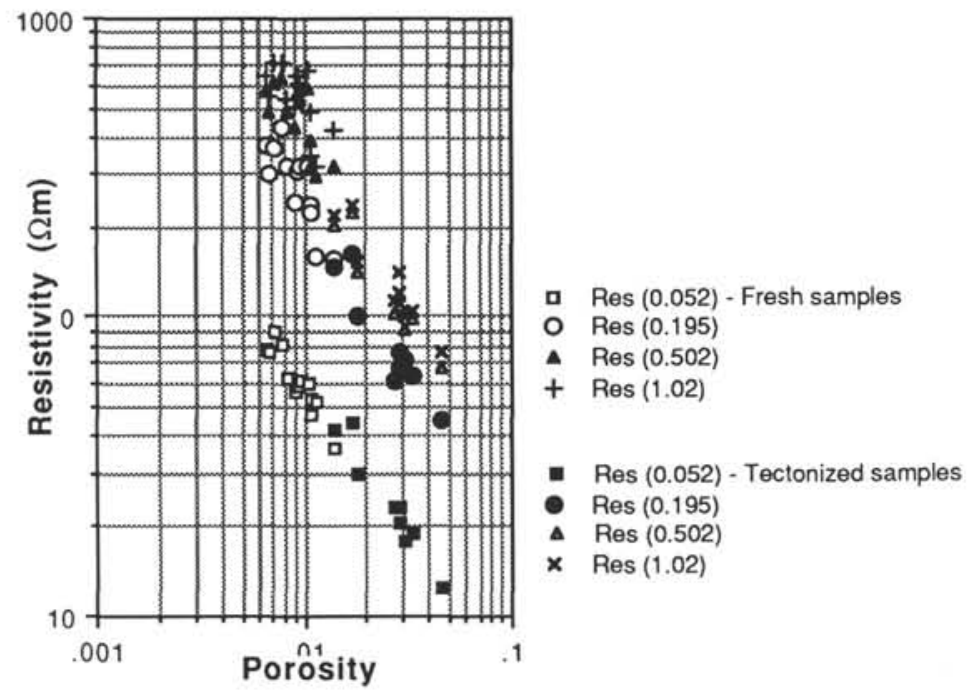

Figure 10. Porosity vs. resistivity for fresh and tectonized samples.

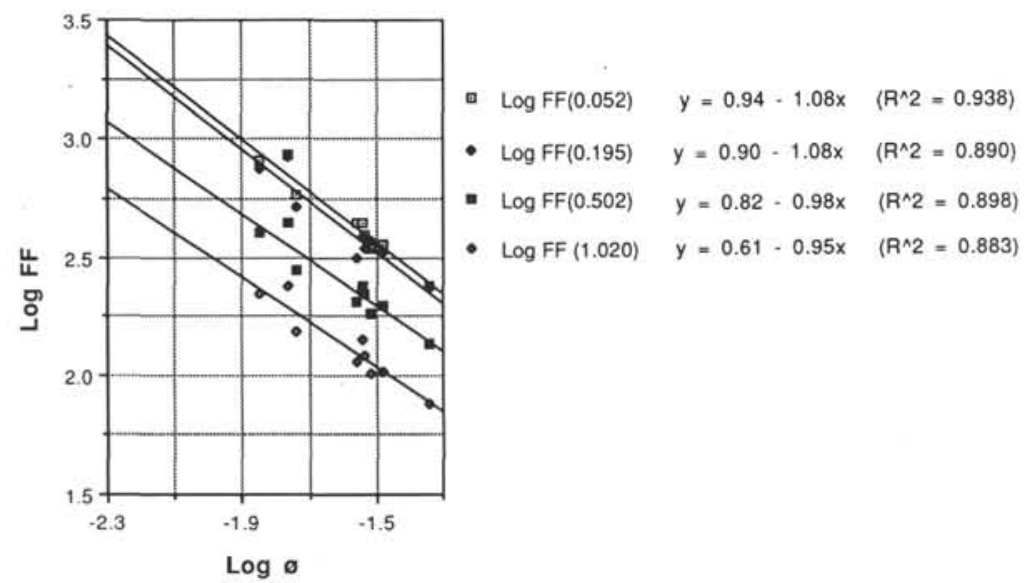

Figure 11. Regressions obtained for formation factor vs. porosity at four different fluid salinities for fresh samples.

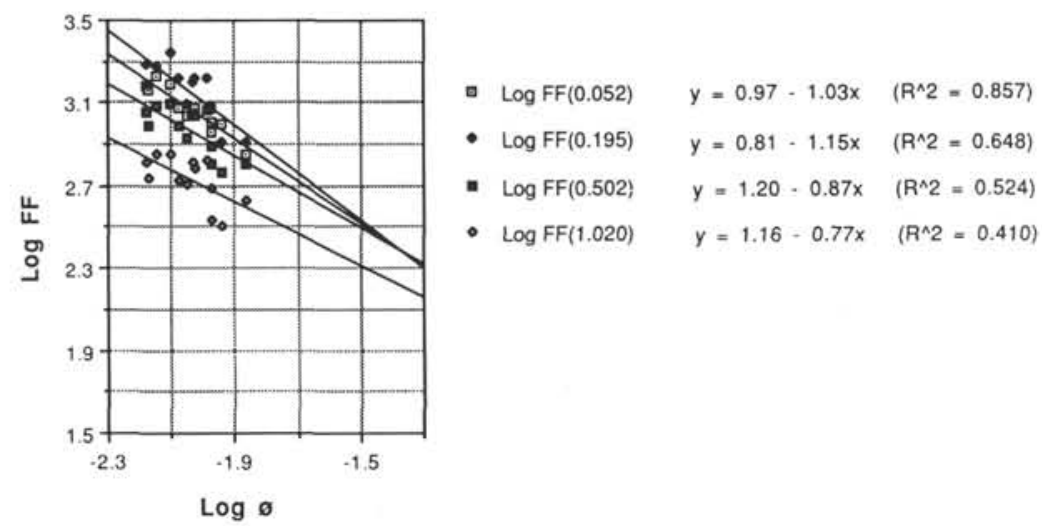

Figure 12. Regressions obtained for formation factor vs. porosity at four different fluid salinities for tectonized samples. 